\title{
On the relative importance of queens and workers to honey production
}

\author{
BP Oldroyd *, RD Goodman \\ with the technical assistance of MA Allaway \\ Plant Research Institute, Burnley Gardens, Swan Street, Richmond Vic, 3121, Australia
}

(Received 2 September 1988; accepted 27 January 1990)

\begin{abstract}
Summary - Colonies of honey bees (Apis mellifera) with different queen genotypes, but identical worker genotype, were established. The 2 groups differed significantly in both weight gain and brood area, indicating that queen genotype influences honey production. In a second experiment, 2 groups of genetically similar queens were inseminated with genetically dissimilar semen. The sire groups did not differ significantly in their honey production over a period of 3 months. It is concluded that queen genotype plays a significant part in colony genotypic merit for honey production, and that selection schemes which do not evaluate queen performance are likely to be only partially successful.
\end{abstract}

Apis mellifera / honey production / queen genotype / queen fecundity / selection scheme

\section{INTRODUCTION}

Chevalet and Cornuet (1982) and Oldroyd (1987) have pointed out that there are characters of queens (such as fecundity), and characters of workers (such as foraging ability) that affect honey production. Understanding the relative importance of queen and worker characters to honey production is crucial to the design of honey bee selection programs. Some authors (e $g$ Milne, 1985) have recommended that honey bee selection should be based entirely on worker characters such as hoarding ability (Milne, 1980a), worker longevity
(Milne, 1980b), or worker pupal weight (Milne, 1980c). However, if characters of queens, such as fecundity, are of crucial importance to honey production, then a selection program must evaluate queen performance in order to be successful.

The common practice of using naturally mated queens for commercial colonies is unsatisfactory if worker characters are important contributors to honey production. This is because drones contribute $50 \%$ to the breeding value of worker offspring. Conversely, if queen characters are the most important components of honey production, then it is more or less irrelevant

\footnotetext{
* Present address: United States Department of Agriculture, Agricultural Research Service, HoneyBee Breeding, Genetics and Physiology Research Laboratory, 1157 Ben Hur Road, Baton Rouge, LA 70820, USA.
} 
with which drones commercial queens are mated.

There are conflicting reports on the relative importance of queen and worker characters to honey production. Soller and Bar-Cohen (1967) computed a very high genetic correlation between brood area and honey yield. Sugden and Furgala (1982); Nelson and Gary (1983), and Szabo (1982) measured significant phenotypic correlations between the 2 characters. These studies suggest a high relative importance of the queen character, fecundity. In contrast, Bar-Cohen et al (1978) showed no significant genetic correlation between honey production and brood area. Oldroyd (1987) suggested that because hybrid queens (which produced more brood than inbred queens in his study) did not produce more honey, that this queen character was relatively unimportant to honey production.

This report describes 2 experiments which shed some light on this problem: a reciprocal cross between 2 lines of bees, and a top cross in which a number of similar queens were mated to different drones.

\section{MATERIALS AND METHODS}

\section{The lines}

Line A was $A m$ caucasica and line $B$ was $A m$ ligustica. The lines were derived from Hawkesbury Agricultural College stock, and inbred by backcrossing, using instrumental insemination. The coefficients of inbreeding for the lines were at least $\mathbf{0 . 5}$, and probably much higher depending on the level of inbreeding of the original queens. Lines $C, D$ and $E$ were single drone mothers obtained from different commercial suppliers.
Crossing and instrumental insemination

A reciprocal cross was made between lines $A$ and $B$. This resulted in colonies that were headed by queens of very different genotype, but populated by workers that were genetically very similar. In a second experiment, lines $A$ and $B$ were each top crossed to lines C, D and E. The top cross resulted in colonies headed by genetically similar queens, but populated by genetically dissimilar workers. For both experiments, queens were raised by the methods of Laidlaw (1979). While it was not possible to raise all the virgins for each experiment at the same time and in the same hive, they were raised in the same season under homogeneous conditions of hive strength and food supply. Queens of different lines were always raised and inseminated in each batch, so there were no common environmental effects for any particular genotype.

Queens were artificially inseminated according to the method of Mackensen and Ruttner (1976). For the inseminations, approximately 50 $\mu$ of semen was collected from several hundred drones derived from a single drone mother. This semen was then run out on a clean glass slide, mixed with the insemination syringe tip, and then taken back into the syringe. This procedure results in mixed spermatozoa (Moritz, 1983; Laidlaw and Page, 1984; Page et al, 1984), and because the drones were taken from colonies headed by purebred queens, should have resulted in colonies of workers that were almost genetically uniform. The procedure makes reciprocal matings of honey bee stocks comparable, in the same way as reciprocal matings between diploid organisms are comparable (Laidlaw and Page, 1987).

\section{Experimental procedures}

After all inseminations had been completed, and the queens were established, the nuclei were standardized with respect to bees, brood and provisions, and then transferred to standard Langstroth hive equipment. The colonies were moved to several sites over the next 10 months, 
Table I. Mean colony weight gains $(\mathrm{kg})$ for various honey flows in the reciprocal trial, an estimate of the effect of the direction of mating, the phenotypic correlation between brood area for that day, and spring colony weight gain. " Significantly different at the $5 \%$ level, as determined from a one-way analysis of variance.

\begin{tabular}{|c|c|c|c|c|c|c|}
\hline \multirow{2}{*}{\multicolumn{2}{|c|}{$\begin{array}{l}\text { Date of } \\
\text { measurement }\end{array}$}} & \multirow{3}{*}{$\begin{array}{l}\text { Predominant } \\
\text { nectar source }\end{array}$} & \multicolumn{2}{|c|}{ Weight gains } & \multirow{3}{*}{$\begin{array}{c}\text { Reciprocal. } \\
\text { effect }\end{array}$} & \multirow{3}{*}{$\begin{array}{l}\text { Phenotypic } \\
\text { correlation }\end{array}$} \\
\hline & & & $\begin{array}{l}\text { Queen } \\
\text { A }\end{array}$ & $\begin{array}{c}\text { genotype } \\
B\end{array}$ & & \\
\hline & & & $(n=6)$ & $(n=5)$ & & \\
\hline \multicolumn{7}{|l|}{1987} \\
\hline \multirow[t]{3}{*}{ March } & 11 & E obliqua & 1.3 & 2.7 & -1.4 & 0.43 \\
\hline & 16 & & 0.8 & 1.0 & -0.2 & 0.16 \\
\hline & 25 & & 1.3 & 0.3 & 1.0 & 0.32 \\
\hline April & 4 & Nil & -0.2 & -0.3 & 0.1 & -0.26 \\
\hline May & 5 & & -1.2 & -0.7 & -0.5 & 0.08 \\
\hline August & 21 & Sugar feed & -3.5 & -4.4 & 0.9 & 0.08 \\
\hline September & 23 & E gracalis & 1.8 & 1.6 & 0.2 & 0.42 \\
\hline \multirow[t]{2}{*}{ October } & 14 & & 7.0 & 10.6 & -3.6 & 0.59 \\
\hline & 28 & $E$ incrassata & 11.6 & 7.1 & $4.5^{\star}$ & 0.46 \\
\hline \multirow[t]{2}{*}{ November } & 10 & & 11.4 & 3.7 & $7.7^{*}$ & 0.20 \\
\hline & 30 & E socialis & 11.7 & 4.1 & $7.6^{*}$ & 0.54 \\
\hline
\end{tabular}

and foraged from various plant species (table I). The reciprocal cross trial was established on 27 February 1987 at Gembrook in southern Victoria. The colonies were overwintered at Knoxfield near Melbourne, and worked spring honey flows at Hattah in northwest Victoria. The top cross colonies worked the Hattah site only. Both experiments were terminated on 30 November 1987.

Brood area and colony weight were measured approximately fortnightly during honey flows. Colony weight gain was used as an index of honey yield (McLellan, 1977). Brood areas (areas of brood cells containing eggs, larvae or pupae of any caste) were determined by placing a $25 \mathrm{~mm}$ wire mesh grid on each comb and then counting the squares and parts of squares that covered brood.

Apart from adding honey supers or removing honey as required, and feeding $0.5 \mathrm{~g}$ of oxytetracycline as a preventative for European brood disease on 2 September 1987, the colonies were not managed in any way. Where supers were added or honey removed, appropriate corrections were made to colony weight gain data.

\section{RESULTS}

\section{Experiment $1 \rightarrow$ top cross}

The mean colony weight gains, for each genotype are given in table II. Analysis of variance was used to test the null hypothesis that there was no sire effect on honey production for the entire season. No effect could be detected $(P>0.1)$, indicating that worker genotype differences had no detectable influence on honey production.

\section{Experiment $2 \rightarrow$ reciprocal cross}

Figure 1 is a plot of the mean brood area of the 2 queen genotypes, with the $5 \%$ least significant difference value computed from a repeated measures analysis of variance, at each measurement. Overall, line 
Table II. Mean colony weight gains in $\mathrm{kg} \pm \mathrm{se}(n)$ of the top cross colonies from September 1987 to November 1987. * Only 1 queen of this genotype survived winter.

\begin{tabular}{cccc}
\hline Queen line & \multicolumn{1}{c}{$\begin{array}{c}\text { Drone line } \\
D\end{array}$} & $E$ \\
\hline A & $51.8 \pm 6.5(2)$ & $64.5 \pm 6.5(2)$ & $58.6 \pm 5.3(3)$ \\
B & $62.2 \pm 5.3(3)$ & $65.8 \pm 6.5(2)$ \\
\hline
\end{tabular}

A queens maintained a significantly larger brood nest than line $\mathrm{B}$ queens $(P=0.019)$. The difference was particularly large during the heavy honey flows from Eucalyptus incrassata and $E$ socialis. During this same period, there were large reciprocal effects detectable for colony weight gain (table l).

The phenotypic correlations between brood area and colony weight gain for the main honey flows between 23 September 1987 and 30 November 1987 were computed for each brood measurement. These correlations are presented in table I. Due to the loss of 3 queens towards the end of the experiment, these correlations are based on 8 observations. None of these correlations are significant at the $5 \%$ level.

\section{DISCUSSION}

The reciprocal cross experiment assumes that worker genotype was identical across queen groups. The strength of this assumption is dependent on the level of mixing of spermatozoa in the spermathecae of queens, and whether any maternally trans-

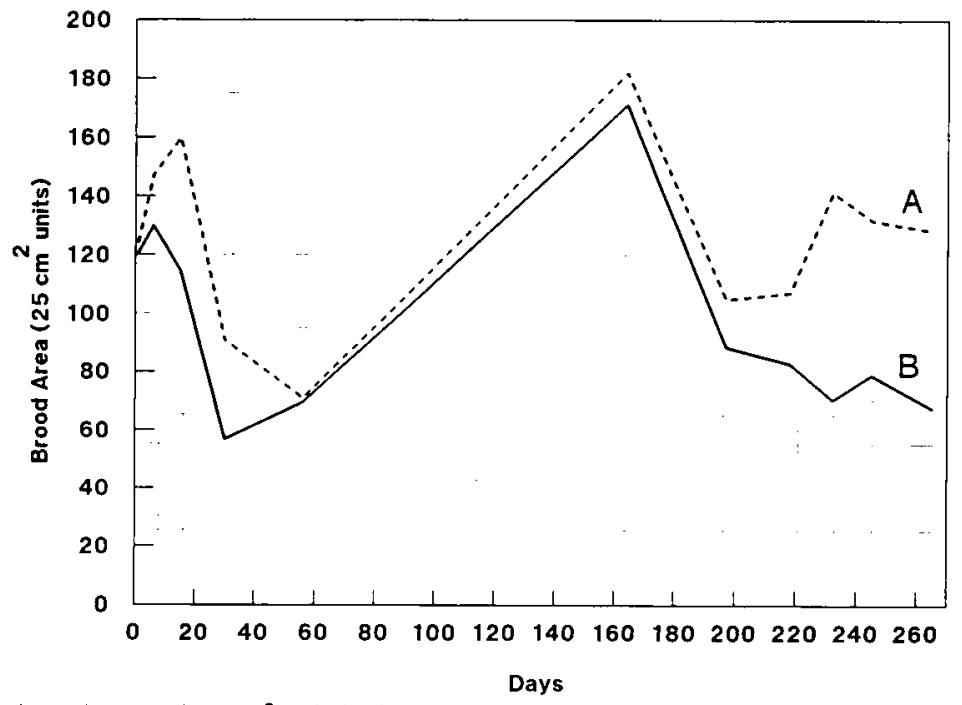

Fig 1. Mean brood areas ( $25 \mathrm{~cm}^{2}$ units) of 2 queen genotypes. The vertical bars are the $5 \%$ LSDs for the corresponding difference in measurements. 
mitted cytoplasmic factors affected worker performance. Physical mixing of the semen, and the time elapsed between insemination and measurements (about 10 months for the spring honey flows) should have resulted in spermatozoa that were homogeneously mixed (Page et al, 1984). Differences between the efficiency of mitochondria and other maternally inherited factors might have affected worker performance. However, these effects are probably small relative to genomic variation.

In the reciprocal cross, Line $A$ queens maintained a larger brood nest than line $B$ queens for all of the season. During periods when nectar was freely available (days $0-25$ and $220-260$ ), this superiority was statistically significant (figure 1). During the spring honey flows at the Hattah site, colony weight gain was significantly larger in the colonies headed by line $A$ queens. Thus, we have demonstrated that queen genotype can affect honey production.

It is likely that one means by which queen genotype affects honey production is via genetic variability for fecundity. The lack of significant phenotypic correlations between brood area and honey production in these experiments is probably due to the low replication. However, this lack of correlation may also indicate that fecundity is not the only queen character that affects honey production. Queens produce pheromones which influence worker behavior (Free, 1987). Nelson and Gary (1983) found that queens differ markedly in their attractiveness to worker bees (presumably due to variation in pheromone production), but that this variability was not correlated with honey production. However, it is not inconceivable that a proportion of the queen effects observed in this experiment were due to pheromones.

Oldroyd (1987) concluded that fecundity was a minor component of honey production under south east Australian condi- tions, and the queen characters were less important than worker characters to honey production because hybrid queens that produced more brood did not produce more honey. Our present data are similar in that we cannot show a direct relationship between brood area and weight gain, as has been demonstrated by Szabo (1982) and Nelson and Gary (1983) in north America. This is probably because the appropriate size of brood nest to maximize honey production, in the variable Australian environment, differs through out the year (Oldroyd and Goodman, 1988).

The top cross experiment was unable to show any effect of drone genotype on honey production. This is in contrast with the results of Oldroyd et al (1985), who demonstrated substantial worker heterosis in certain rare crosses between lines. In the preparation of the colonies for the top cross experiment, a large number of overwintering queens were lost, substantially reducing the level of replication. Although the null hypothesis (that drone genotype is irrelevant to colony weight gain) cannot be rejected from the data presented here, it would be unreasonable to conclucle that worker genotype is entirely irrelevant to honey production.

The reciprocal cross experiment has consequences for the design of future bee breeding programs. The importance of queen characters to honey production has been demonstrated, and would indicate that any selection program that completely ignored queen characters, as proposed by Milne (1985), would be only partially successful.

Although no significant phenotypic correlation between brood area and honey production could be demonstrated, both characters differed significantly between the 2 lines during honey flows. This suggests that queens with high fecundity can improve production. Oldroyd and Good- 
man (1988) showed that hybrid queens maintain larger brood nests than inbred queens. Thus, the use of hybrid queens may be one means of improving honey yield.

\section{CONCLUSION}

We conclude that both worker and queen characters are important components of honey production. Their relative importance remains somewhat unclear. The conclusive experiment, which remains to be done, would be a large scale highly replicated top cross. However, since the genotype of the drones with which commercial queens mate does not influence queen characters, shown here to be important to honey yield, and because no sire effects could be demonstrated in the top cross experiment, we may deduce that natural mating with more or less uncontrolled populations of drones may not substantially detract from the honey producing potential of commercial queens, which have been produced from dams of high breeding value.

\section{ACKNOWLEDGMENTS}

This work was supported by the Australian Honey Research Council. As always, thanks go to Bob McDonald for advice on honeyflows. $\mathrm{Dr}$ Ken Russell helped with the statistics.

\section{Résumé - Importance relative de la reine et des ouvrières dans la produc- tion de miel. Deux groupes de reines gé- nétiquement semblables ont été insémi- nées avec du sperme provenant de 3 groupes de mâles génétiquement dissem- blables pour obtenir un top-cross. Le gain de poids de la colonie a été mesuré au cours d'une miellée de printemps. Les}

groupes de père différent ont présenté le même gain de poids (tableau II).

Dans une seconde expérience, 2 lignées ont été croisées réciproquement, ce qui a donné 2 groupes de colonies composées de reines génétiquement différentes mais d'ouvrières génétiquement semblables. Les colonies ont été placées en divers endroits durant les 10 mois suivants. La surface de couvain et le gain de poids ont été mesurés environ tous les 15 jours pendant les miellées. La figure 1 montre que la surface moyenne de couvain n'est pas la même pour les 2 groupes de reines. Au cours de la principale miellée de printemps, les 2 groupes issus de reines différentes ont présenté un gain de poids significativement différent (tableau I). II n'y a, pour aucune des mesures, de corrélation phénotypique significative entre la surface de couvain et le gain de poids de la colonie au cours de la miellée de printemps (tableau I). Ces expériences montrent que le génotype de la reine influence la production de miel et, donc, que tout programme de sélection ne tenant pas compte des caractères de la reine ne réussira que partiellement.

Zusammenfassung - Über die relative Bedeutung von Königin und Arbeitsbienen für die Honigproduktion. Zwei Gruppen genetisch ähnlicher Königinnen wurden mit Samen von drei Gruppen genetisch unähnlicher Drohnen besamt, um eine Top-Kreuzung zu erzielen. Die Gewichtszunahmen der Völker wurden in einer Frühjahrstracht gemessen. Die Gruppen verschiedener väterlicher Abstammung unterschieden sich nicht in der $\mathrm{Ge}$ wichtszunahme (Tabelle I). In einem zweiten Experiment wurde zwischen zwei Linien eine reziproke Kreuzung durchgeführt. Dadurch entstanden zwei Völkergruppen mit genetisch unähnlichen Königinnen, aber mit genetisch ähnlichen 
Arbeiterinnen. Die Völker wurden während der folgenden 10 Monate auf mehrere Trachtplätze gebracht. Während der Tracht wurden in Abständen von etwa 14 Tagen Bruttläche und Volksgewicht gemessen. Abb 1 zeigt, daB die mittlere Brutfläche der beiden Königinnengruppen verschieden war. Während der Haupttracht im Frühjahr hatten die beiden Gruppen signifikant verschiedene Gewichtszunahmen (Tabelle I). Für keines der Maße bestand während der Frühjahrstracht eine signifikante phenotypische Korrelation zwischen der Brutfäche und der Zunahme des Volksgewichtes (Tabelle I). Diese Experimente haben gezeigt, daß der Genotyp der Königin die Honigproduktion beeinflußt. Damit wird gezeigt, daß jedes Selektionsprogramm nur teilweise erfolgreich sein wird, in dem die Königinnenmerkmale nicht berücksichtigt werden.

\section{REFERENCES}

Bar-Cohen R, Alpern G, Bar-Anan R (1978) Progeny testing and selecting Italian queens for brood area and honey production. Apidologie 9, 95-100

Chevalet $\mathrm{Cl}$, Cornuet JM (1982) Etude théorique sur la sélection du caractère «production de miel" chez l'abeille. I. Modèle génétique et statistique. Apidologie 13, 39-65

Free JB (1987) Pheromones of Social Bees. Cornell University Press, New York

Laidlaw HH (1979) Contemporary Queen Rearing. Dadant \& Sons, Hamilton

Laidlaw HH, Page RE (1984) Polyandry in bees (Apis mellifera $\mathrm{L}$ ): sperm utilization and intracolony genetic relationships. Genetics 108 , 985-997

Laidlaw HH, Page RE (1987) Mating designs. In: Bee Breeding and Genetics (Rinderer T, ed) Academic Press, Orlando, 323-342

Mackensen O, Ruttner $F$ (1976) The insemination procedure. In: The Instrumental Insemination of the Queen Bee (Ruttner F, ed), Apimondia, Bucharest, 69-86
McLellan AR (1977) Honeybee colony weight gain as an index of honey production and nectar flow: a critical evaluation. $J$ Appl Ecol $14,401-408$

Milne CP (1980a) Laboratory measurement of honey production in the honeybee. 1. A model of hoarding behaviour by caged workers. $J$ Apic Res 19, 122-126

Milne CP (1980b) Laboratory measurement of honey production in the honeybee. 2. Longevity or length of life of caged workers. $J$ Apic Res 19, 172-175

Milne CP (1980c) Laboratory measurement of honey production in the honeybee. 3. Pupal weight of the worker. $J$ Apic Res 19, 176-178

Milne CP (1985) The need for laboratory tests in breeding honeybees for improved honey production. J Apic Res 24, 237-242

Moritz RFA (1983) Homogenous mixing of honeybee semen by centrifugation. J Apic Res 22, 249-255

Nelson DL, Gary NE (1983) Honey productivity of honeybee colonies in relation to body weight, attractiveness and fecundity of the queen. J Apic Res 22, 209-213

Oldroyd BP (1987) Are queens or workers more important to honey production? In: Africanized Honey Bees and Bee Mites (Needham G, Page R, Delfinado-Baker M, Bowman E, eds) Ellis Horwood, Chichester, 91-96

Oldroyd BP, Moran C, Nicholas FW (1985) Diallel crosses of honeybees. 1. A genetic analysis of honey production using a fixed effects model. J Apic Res 24, 243-249

Oldroyd BP, Goodman RD (1988) Heterosis and inbreeding in queen bees in relation to brood area and honey production. Aust J Agric Res 39, 959-964

Page RE, Kimsey RB, Laidlaw HH (1984) Migration and dispersal of spermatozoa in spermathecae of queen honeybees (Apis mellifera L). Experientia 40, 182-184

Soller M, Bar-Cohen R (1967) Some observations on the heritability and genetic correlation between honey production and brood area in the honey bee. J Apic Res 6, 37-43

Sugden MA, Furgala B (1982) Evaluation of six commercial honey bee (Apis mellifera L) stocks used in Minnesota. Am Bee $J$ 122, 283-286

Szabo TI (1982) Phenotypic correlations between colony traits in the honeybee. Am Bee $J 122,711-716$ 